\title{
PROFESSIONAL AND INSTRUCTIONAL RESPONSIBILITIES: BASIS FOR IMPROVEMENT AMONG GENERAL EDUCATION FACULTY
}

\author{
"Dr. Jose Lizael B. Lampinez
}

\begin{tabular}{l}
\hline Paper Received: 06.03.2020 / Paper Accepted: 30.05.2020 / Paper Published: 04.06.2020 \\
Corresponding Author: Dr Jose Lizael B. Lampinez; Email: jose.lampinez@ @chmsc.edu.ph; doi:10.46360/globus.xxxxxxxx \\
\hline
\end{tabular}

\begin{abstract}
This study aimed to determine the professional and instructional responsibilities among General Education faculty of a Maritime School in Bacolod City during the Second Semester of the School Year 2016-2017.

The respondents was taken from the total population of three thousand two hundred forty three $(3,243)$ which comprises of General Education Faculty, Bachelor of Science in Marine Transportation and Bachelor of Science in Marine Engineering students and ESLP students from first year to fourth year. Using the Slovin's formula with $5 \%$ margin of error, 352 will be taken as the sample population of the respondents.

The study revealed the following results. The level of professional and instructional responsibilities of the General Education faculty is very high as perceived by the faculty and the students of a Maritime School in Bacolod City. This finding can be attributed to the various training as well as from the constant feedback derived from the faculty evaluation of the department heads of the school.

The perceptions of the faculty and the students as regards the level of professional and instructional responsibilities of the faculty are comparably the same. The perceptions of the faculty and the students as regards the level of professional and instructional responsibilities of the faculty are comparably the same.

As for the recommendations, General Education faculty department heads should improve observation, evaluation, and feedback mechanism. General Education faculty professional relationships should be enhanced. Preparation and planning of instruction is always a must. A conducive classroom environment, readiness of instruction, and professional responsibilities must always be observed.
\end{abstract}

Keywords: Professional Responsibilities, Instructional Responsibilities, General Education, Maritime School, Conducive Classroom Environment.

\section{Introduction}

The Philippines, according to Maritime Industry Authority (MARINA 2008), is reported as the largest global supplier of worlds' outstanding seafarers. In a larger perspective, the Department of Labor and Employment (DOLE memo circ. \# 23, 2010) has recorded a tremendous increase of seafarers' attending seminars on DOLE assisted Pre- Departure Orientation Seminar (PDOS), a clear indication on how enticing seafaring professionals from the Philippines are, for shipping companies here and abroad.

In order to maintain competitiveness in the maritime industry and to meet the uppermost demands of different stakeholders' in the shipping businesses, the academic institutions where these seafaring professionals came from, plays a significant role (Nakpil, 2008).

In a Maritime School in Bacolod City, holistically, students are expected to be a well-rounded individual. Though resilient, they are groomed to become brave sailors and leaders of our homeland. But how could that be according to Gonzales (2006), if mentors inside the classrooms lack the professional and instructional motivations to maintain if not exceed the expectations of the students and that of the global maritime world?

The European standards in maritime industry had posed a threat in the employability of Filipino seafarers. A massive upgrading of all equipment and that of the standards of curriculum set in the academic area at school in order to be at par to the playing field of the Europeans', needs to be reviewed and evaluated, only to draw alongside with the standards being laid down to Filipino Seafarers (STCW 2010).

The need for an evaluation on the professional and instructional responsibilities among general education faculty of the maritime department as basis for self-improvement is a must.

Wright (2002) stated that defining and measuring teaching effectiveness plays an important role in many of the decisions made in higher education. Typically, teaching effectiveness is measured through some form of a student questionnaire that has been specifically designed to measure observed teaching styles or behaviors. In many universities,

*Carlos Hilado Memorial State College, Talisay City, Negros Occidental, Philippines.

Email: jose.lampinez@chmsc.edu.ph 
student ratings are used as one (sometimes the only and often the most influential) measure of teaching effectiveness (Gera, 2013).

Through the perceptions of the students and that of the faculty concerned, the handicap for a better classroom atmosphere and that of learning instructions which is conducive for learners can be overhauled and troubleshoot (Pefiangco, 2003).

De Guzman (2007), in his book "Evaluative Teaching: A Tool for an Effective Classroom Management", emphasizes that the faculty should be given the chance to evaluate himself first, before he will be subjected to a different calculation by others.

Professional instructors are expected to assume the normal teaching load of faculty of similar rank in their department or school. Teaching loads differ from one school to another and can even vary among departments within a single school. Individuals should consult with their department chair, dean or vice president if they have any questions about the number of courses they are expected to teach. Variations from the norm are permitted with the authorization of the department chair and dean or vice president (Abrani, 2001).

The Manual of Faculty is very clear about the responsibilities of teachers to their students. While faculty is given considerable freedom in deciding what they teach, their courses are subject to the approval of their department or school in order to ensure that they contribute to the curricular programs of the University. Each school has its own procedures for determining the instructional assignments of its faculty. Typically, these decisions are made by the individual officer in consultation with the department chair or dean, taking into account the need to ensure that the department or school meets its instructional obligations. New courses must also be approved by the appropriate Committee(s) on Instruction. Faculty should contact their department or dean's office for information on the preparation of course proposals and for the deadlines for their submission. Proposals for major changes to existing courses, such as in the number of points of credit, their level, or manner of instruction, also need approval of the appropriate Committee(s) on Instruction and the dean or vice president (Kelly, 2012).

It is the responsibility of the faculty to meet all scheduled classes. In the event of unavoidable absence due to emergencies, religious holidays, or other scheduling conflicts, an officer must reschedule missed classes, arrange for a replacement, or provide alternative instruction.
Should an officer be absent for an extended period due to illness or injury, the department or school will provide substitute instructors for his or her courses (Chang, 2002).

In conducting their classes, faculty should promote an atmosphere of mutual tolerance, respect, and civility. They should allow the free expression of opinions within the classroom that may be different from their own and should not permit any such differences to influence their evaluation of their students' performance. They should confine their classes to the subject matter covered by their courses and not use them to advocate any political or social cause. These principles of classroom conduct help to promote a healthy learning environment, but they do not limit the authority of the faculty to determine the actual content of their courses nor do they interfere with the right of faculty to express personal political views outside of the classroom in the manner of their choosing. Students who feel that their faculty has not abided by these principles may file a complaint according to procedures described in the student handbook (Kelly, 2012).

Faculty is expected to give students clear written statements of course requirements and to judge them solely on the basis of academic performance. During the course of the term, they should notify the academic advisers of those students who are at risk of failing their courses. At the end of the term, they are expected to submit their grades to the Registrar in a timely manner.

This study is concerned with the importance of professional and instructional responsibilities to be used as basis for improvement among General Education Faculty of a Maritime School.

\section{Statement of the Problem}

This study aimed to determine the professional and instructional responsibilities among General Education faculty of a Maritime School in Bacolod City during the Second Semester of the School Year 2015-2016.

1. What is the level of professional and instructional responsibilities of the General Education faculty as evaluated by themselves and by their students?

2. Is there a significant difference in the students' level of perception of their teachers' professional and instructional responsibilities and the self-evaluation of the General Education faculty?

3. Is there a significant relationship in the teachers' evaluation of themselves and the students' evaluation of their professional and instructional responsibilities? 


\section{Hypothesis}

1. There is no significant difference in the students' level of perception of their teachers' professional and instructional responsibilities and the self-evaluation of the General Education faculty.

2. There is no significant relationship in the teachers' evaluation of themselves and the students' evaluation of their professional and instructional responsibilities.

\section{Materials and Methods}

\section{Research Design}

The study employed the descriptive design using quantitative approach. To gather the needed data, the survey methods were primarily used.

\section{Respondents of the Study}

The respondents will be taken from the total population of three thousand two hundred forty three $(3,243)$ which comprises of General Education Faculty, Bachelor of Science in Marine
Transportation and Bachelor of Science in Marine Engineering students and ESLP students from first year to fourth year. Using the Slovin's formula with $5 \%$ margin of error, 352 will be taken as the sample population of the respondents.

The groupings will be used as stratum in the sampling. There will be eleven (11) groups in the population. In as much as 352 is equal to $10.85 \%$ of 3,288 , every group number will be multiplied by 1085. Respondents will be picked randomly according to the number of the group in the population. The distribution of the respondents' population and the sample according to group is shown in Table 1.

The respondents will be subjected to a one time survey evaluation in the purpose of determining professional and instructional responsibilities of the General Education faculty of a Maritime School in Bacolod City, finding its significant differences when respondents will be grouped according to variables.

Table 1: Profile of the General Education Faculty

\begin{tabular}{|l|l|l|}
\hline $\begin{array}{l}\text { General Education } \\
\text { Faculty }\end{array}$ & \multicolumn{2}{|l|}{ Population Distribution } \\
\cline { 2 - 3 } & $\begin{array}{l}\text { Total } \\
\text { Population } \\
\text { N }\end{array}$ & $\begin{array}{l}\text { Percentage } \\
\%\end{array}$ \\
\hline Social and Science & & \\
\hline English and Humanities & & \\
\hline Math & & \\
\hline Allied and Science & & \\
\hline Total & 45 & \\
\hline
\end{tabular}

Table 2: Profile of the Respondents

\begin{tabular}{|c|c|c|c|c|}
\hline \multicolumn{2}{|c|}{ Respondents } & \multicolumn{3}{|c|}{ Population Distribution } \\
\hline & & $\begin{array}{l}\text { Total } \\
\text { Population } \\
\text { N }\end{array}$ & $\begin{array}{l}\text { Sample } \\
\text { Population } \\
\text { N }\end{array}$ & $\begin{array}{l}\text { Percentage } \\
\%\end{array}$ \\
\hline \multirow[t]{5}{*}{ BSMT } & Students First Year & 596 & 65 & 18 \\
\hline & Second Year & 585 & 63 & 18 \\
\hline & Third Year & 641 & 70 & 20 \\
\hline & Fourth year & 26 & 3 & 1 \\
\hline & ESLP-MD & 56 & 6 & 2 \\
\hline \multirow[t]{6}{*}{ BSMarE } & Students First Year & 479 & 52 & 15 \\
\hline & Second Year & 403 & 44 & 12 \\
\hline & Third Year & 361 & 39 & 11 \\
\hline & Fourth year & 28 & 3 & 1 \\
\hline & ESLP-ME & 68 & 7 & 2 \\
\hline & TOTAL & 3,243 & 352 & 100 \\
\hline
\end{tabular}




\section{Research Instrument}

To answer the specific questions in this investigation, a researcher-made questionnaire was used.

The questionnaire is composed of two parts. Part I is mainly the profile of the respondents, name of the respondents which is optional, areas of discipline for the Faculty and year level and specific course for the students. Part II on the other hand comprises the questionnaire about Professional Responsibilities and Part III about Instructional Responsibilities. The separate questionnaires were administered to students and the faculty. A Likert scale was used to rate each item.

The questionnaire used underwent face and content validation by three members of the Research Committee. The comments and corrections were taken into consideration in the finalization of the instrument. In order to determine the validity and reliability, the researcher used the Cronbach's alpha. A reliability coefficient of 0.712 was met.

In the questionnaire for students, the following scale and interpretation was used:

\begin{tabular}{|l|l|l|}
\hline Numerical Value & Description & Interpretation \\
\hline 5 & Strongly Agree & $\begin{array}{l}\text { The teacher clearly and convincingly possesses and } \\
\text { displays the said characteristic or skill at all times. }\end{array}$ \\
\hline 4 & Agree & $\begin{array}{l}\text { The teacher possesses or displays the said characteristic } \\
\text { or skill most of the time. }\end{array}$ \\
\hline 3 & $\begin{array}{l}\text { Neither Agree nor } \\
\text { Disagree }\end{array}$ & $\begin{array}{l}\text { I am not sure. There is nothing about the teacher that I } \\
\text { can agree or disagree on. }\end{array}$ \\
\hline 2 & Disagree & $\begin{array}{l}\text { The teacher does not possess or display the said } \\
\text { characteristic or skill. }\end{array}$ \\
\hline 1 & Strongly Disagree & $\begin{array}{l}\text { The teacher clearly and convincingly does not possess } \\
\text { or display the said characteristic or skill. }\end{array}$ \\
\hline
\end{tabular}

Self -evaluation by the faculty was based on the following scale and interpretation:

\begin{tabular}{|l|l|l|}
\hline Numerical Value & Description & Interpretation \\
\hline 5 & Strongly Agree & $\begin{array}{l}\text { I clearly and convincingly possess and display the } \\
\text { said characteristic or skill at all times. }\end{array}$ \\
\hline 4 & Agree & $\begin{array}{l}\text { I possess or display the said characteristic or skill } \\
\text { most of the time. }\end{array}$ \\
\hline 3 & $\begin{array}{l}\text { Neither Agree nor } \\
\text { Disagree }\end{array}$ & $\begin{array}{l}\text { I am not sure. If I possess or display the said } \\
\text { characteristics or skill. }\end{array}$ \\
\hline 2 & Disagree & $\begin{array}{l}\text { I do not possess or display the said characteristic or } \\
\text { skill. }\end{array}$ \\
\hline 1 & Strongly Disagree & $\begin{array}{l}\text { I clearly and convincingly do not possess or display } \\
\text { the said characteristic or skill. }\end{array}$ \\
\hline
\end{tabular}

\section{Validity of the Research Instrument}

The research-made questionnaire was subjected to face and content validation by three experts. Their suggestions and recommendations were used as basis for the modification and finalization of the questionnaire.

\section{Data Gathering Procedure}

A proposal form from the Research Office was provided, and then with the Research Coordinator's approval, the researcher distributed the instruments to the Maritime School Education faculty and Maritime students during the school year 20162017. 
The questionnaires were administered by the researchers personally. Upon retrieval of the accomplished questionnaire, data were analyzed and interpreted using the Statistical Packages for Social Sciences (SPSS) software.

\section{Statistical Tools}

The following are the statistical tools that were used in treating the data.

For problem no. 1, in order to measure the level of professional and instructional responsibilities among general education faculty, Mean and sd were used.

The computed mean ratings were interpreted using the following scale:

$\begin{array}{ll}\text { Score } & \text { Description } \\ 4.21-5.00 & \text { Very High } \\ 3.41-4.20 & \text { High } \\ 2.61-3.40 & \text { Moderate } \\ 1.81-2.60 & \text { Low } \\ 1.00-1.80 & \text { Very Low }\end{array}$

For problem no. 2, in order to determine the significant difference among students' level of perception on the faculty's professional and instructional responsibilities, $\mathbf{T}$ - test was used.

For problem no. 3, in order to determine the significant relationship between the faculty's selfevaluation and that of the students' evaluation with regards to their professional and instructional responsibilities, Pearson Product Moment Correlation Coefficient was used.

\section{Conclusion and Recommendations}

The level of professional and instructional responsibilities of the General Education faculty is very high as perceived by the faculty and the students of a Maritime School in Bacolod City. This finding can be attributed to the various training as well as from the constant feedback derived from the faculty evaluation of the department heads of the school.

The perceptions of the faculty and the students as regards the level of professional and instructional responsibilities of the faculty are comparably the same. The perceptions of the faculty and the students as regards the level of professional and instructional responsibilities of the faculty are comparably the same.

As for the recommendations, General Education faculty department heads should improve observation, evaluation, and feedback mechanism. General Education faculty professional relationships should be enhanced. Preparation and planning of instruction is always a must. A conducive classroom environment, readiness of instruction, and professional responsibilities must always be observed.

The school should solicit their faculty's responses to what could be done, beyond compensation, to help improve their teaching. There should be increased instructional support, improved technology in the classroom, improved class facilities, and equitable treatment in the use of resources to help enhance student learning.

A follow-up of the current study should be conducted in determining the professional and instructional responsibilities not only in a maritime school in Bacolod City but the whole region of Western Visayas.

\section{Conflict of Interest}

There is no Conflict of Interest in this work.

\section{References}

1. Abrami, P.C., (2001). Business students' perceptions of faculty. The International Journal of Educational Management, 12-22.

2. Agarwal, Nidhi and Gupta, Jayanta Das, (2018). "School Effectiveness in the Development of High School Children". International Journal of Academic Research and Development, 3(4); 200-202; doi: 10.5281/zenodo.3806990.

3. Agarwal, Nidhi and Rani, Priyanka, (2017). "Relevance of Teaching of Isms in the B.Ed Curriculum". Shodh Snchayan A Referred Research Journal and A Complete Periodical Dedication to Humanities and Social Science Research, 8(2), ISSN: 0975-1254(print), ISSN: 2249-9180 (ONLINE). doi: 10.5281/ zenodo. 3839793.

4. Agarwal, Nidhi and Pundir, Neelam, (2017). "Information and Communication and Its Importance". Ambikeya Journal of Education, 8, 40-42, ISSN: 0975-9735.

5. Agarwal, Nidhi and Verma, Monika, (2019). A Study on Taxonomy of Innovations. Globus An International Journal of Management \& IT, 11(1); 57-64, ISSN: 0975-721X.

6. Amani, N., (2014). Major steps we can take to avoid problems with the performance appraisal process. Retrieved September 20, 2014, from http://nteboya.blogspot.com/2014/06/majorsteps-we-can-take-to-avoid.html

7. Arnold, J., Cooper, C. and Robertson, I., (1998). Work Psychology: Understanding Human Behavior in the Workplace. $3^{\text {rd }}$ ed. Pearson Education: Prentice Hall.

8. Berghe, J.V., (2011). Job Satisfaction and Job Performance. Degree Thesis - International Business (Published Thesis). 
9. Bindslev, J.L., (2006). Organizational Theory. Jorgen Laegaard, Mille Bindslev \& Ventus Publishing Aps.

10. Boswell, W.R., (2002). Separating the developmental and evaluative performance appraisal uses. Journal of Business \& Psychology, 16(3); 391-412.

11. Chang, T.S., (2001). Teachers College Faculty Attitudes toward Student Ratings: Comparison between Required Policy and Optional policy. San Francisco, CA: American Psychological Association (APA).

12. Chang, T.S., (2002). Student Perceptions of Student Ratings of Instruction: Does School Policy Really Matter? Graduate Institute of Compulsory Education, 1-29.

13. Chiang, K.A., (2003). "Factors driving consumer intention to shop online: An Empirical Investigation,". Journal of Consumer Psychology, 13, 1 -2 .

14. Davis, D., (2008). Is there a problem with adjuncts? www.teachingcollegeenglish.

15. Flaniken, F.W., (2009). Retrieved September 20, 2014, from http://www.proquest.com/en-

US/products/dissertations/individuals.shtml

16. Flaniken, F.W., (2009). Performance Appraisal Systems In Higher Education: An Exploration of Christian Institutions.

17. Gera, S.M., (2013). Student Evaluation of Teaching Effectiveness (SET): An SEM Study in Higher. International Journal of Business and Social Science, 289-298.

18. Hobsone, S.M., (2001). Understanding student evaluations. College Teaching, 26-31.

19. Hoshower, Y.C., (2003). Student Evaluation of Teaching: an assessment of student perception and motivation. Assessment \& Evaluation in Higher Education, 28(1); 71-88.

20. Kelly, M., (2012). Student Evaluations of Teaching Effectivenss: Considerations of Ontario Universities. ISSN: 1704-4197 (online), 1-15.

21. Kumar, Puneet and Mishra, Sugam, (2019). Higher Education in Prospective of Quality. Globus Journal of Progressive Education, 9(2); 56-62, ISSN: 2231-1335.

How to cite this article:

Lampinez, Jose Lizael B., (2020). Professional and Instructional Responsibilities: Basis for Improvement among General Education Faculty. Globus Journal of Progressive Education, 10(1): 120-125. 